\title{
Article \\ The Preservation of PPAR $\gamma$ Genome Duplicates in Some Teleost Lineages: Insights into Lipid Metabolism and Xenobiotic Exploitation
}

\author{
Inês Páscoa $^{1}$, Elza Fonseca ${ }^{1} \mathbb{D}$, Renato Ferraz ${ }^{1}$, André M. Machado ${ }^{1,2} \mathbb{D}^{\mathbb{D}}$, Francisca Conrado ${ }^{1}$, Raquel Ruivo ${ }^{1} \mathbb{D}$, \\ Isabel Cunha $1, * \mathbb{D}$ and Luís Filipe C. Castro $1,2, * \mathbb{D}$ \\ 1 CIIMAR/CIMAR - Interdisciplinary Centre of Marine and Environmental Research, University of Porto, \\ 4450-208 Porto, Portugal; mipascoa@gmail.com (I.P.); fonseca.ess@gmail.com (E.F.); \\ renatobarbosaferraz@gmail.com (R.F.); andre.machado@ciimar.up.pt (A.M.M.); \\ fi.silva@campus.fct.unl.pt (F.C.); ruivo.raquel@gmail.com (R.R.) \\ 2 Department of Biology, FCUP—Faculty of Sciences, University of Porto, 4169-007 Porto, Portugal \\ * Correspondence: isabel.cunha@ciimar.up.pt (I.C.); filipe.castro@ciimar.up.pt (L.F.C.C.); \\ Tel.: +351-223-401-800 (L.F.C.C.)
}

check for

updates

Citation: Páscoa, I.; Fonseca, E.;

Ferraz, R.; Machado, A.M.; Conrado, F.; Ruivo, R.; Cunha, I.; Castro, L.F.C. The Preservation of PPAR $\gamma$ Genome Duplicates in Some Teleost Lineages: Insights into Lipid Metabolism and Xenobiotic Exploitation. Genes 2022, 13, 107. https://doi.org/10.3390/ genes13010107

Academic Editor: Sebastián

E. Ramos-Onsins

Received: 30 November 2021

Accepted: 31 December 2021

Published: 4 January 2022

Publisher's Note: MDPI stays neutral with regard to jurisdictional claims in published maps and institutional affiliations.

Copyright: (c) 2022 by the authors. Licensee MDPI, Basel, Switzerland. This article is an open access article distributed under the terms and conditions of the Creative Commons Attribution (CC BY) license (https:// creativecommons.org/licenses/by/ $4.0 /)$.

\begin{abstract}
Three peroxisome proliferator-activated receptor paralogues (PPAR $\alpha,-\beta$ and $-\gamma)$ are currently recognized in vertebrate genomes. PPAR $\gamma$ is known to modulate nutrition, adipogenesis and immunity in vertebrates. Natural ligands of PPAR $\gamma$ have been proposed; however, the receptor also binds synthetic ligands such as endocrine disruptors. Two paralogues of PPAR $\alpha$ and PPAR $\beta$ have been documented in teleost species, a consequence of the 3R WGD. Recently, two $P P A R \gamma$ paralogue genes were also identified in Astyanax mexicanus. We aimed to determine whether the presence of two $P P A R \gamma$ paralogues is prevalent in other teleost genomes, through genomic and phylogenetic analysis. Our results showed that besides Characiformes, two PPAR $\gamma$ paralogous genes were also identified in other teleost taxa, coinciding with the teleost-specific, whole-genome duplication and with the retention of both genes prior to the separation of the Clupeocephala. To functionally characterize these genes, we used the European sardine (Sardina pilchardus) as a model. PPAR $\gamma A$ and PPAR $B$ display a different tissue distribution, despite the similarity of their functional profiles: they are unresponsive to tested fatty acids and other human PPAR $\gamma$ ligands yet yield a transcriptional response in the presence of tributyltin (TBT). This observation puts forward the relevance of comparative analysis to decipher alternative binding architectures and broadens the disruptive potential of man-made chemicals for aquatic species.
\end{abstract}

Keywords: PPAR ; genome duplication; Clupeocephala; sardine; organotins

\section{Introduction}

Nuclear receptors (NRs) are metazoan-specific transcription factors that modulate the expression of target genes involved in multiple aspects of physiological homeostasis e.g., [1,2]. Among NRs, we find the peroxisome proliferator-activated receptors (PPAR $\alpha$, $-\beta$ and $-\gamma$ ), which control multiple aspects of lipid metabolism and have been described in vertebrate and invertebrate species [3,4]. PPAR $\alpha, P P A R \beta$ and PPAR $\gamma$ are classical examples of paralogous genes originated from whole-genome duplication (WGD) events that occurred in the vertebrate ancestor. In some invertebrates, such as Saccoglossus kowalevskii (Hemichordata) [5], nonvertebrate chordates (amphioxus (Cephalochordata) and sea squirts (Tunicata) [5,6], and protostome molluscs [4,7], a single PPAR orthologous gene is found. On the other hand, in some teleost species, PPAR $\alpha$ and PPAR $\beta$ genes duplicated during the teleost-specific third round of WGD (3R WGD) event [6-12]. Intriguingly, in the case of $P P A R \gamma$, a second gene was reported in Astyanax mexicanus (Mexican tetra) [13].

In general, PPAR paralogues display a characteristic gene expression pattern, modulating different metabolic processes; specifically, $P P A R \gamma$ is highly expressed in tissues 
with active lipid metabolism [14], mostly due to its involvement in the regulation of adipogenesis and lipid storage as well as lipid metabolism and energy homeostasis [15]. In addition to this, other $P P A R \gamma$-related processes have also been described. With respect to teleosts, $P P A R \gamma$ has been associated with the regulation of nutrition [16,17], adipogenesis $[13,18]$, immunity $[19,20]$ and was shown to be targeted and disrupted by environmental chemicals $[6,16,21]$.

Proposed endogenous ligands of PPAR $\gamma$ include polyunsaturated fatty acids (PUFA), such as docosahexaenoic acid (DHA), eicosapentaenoic acid (EPA), arachidonic acid (ARA) and linoleic acid (ALA), as well as some of their derivatives, particularly oxygenated metabolites such as oxylipins; in addition, some monounsaturated fatty acids (MUFA) may also act as PPAR $\gamma$ ligands [22-26]. Regarding synthetic ligands, thiazolidinediones that function as insulin sensitizers in humans, and several nonsteroidal anti-inflammatory drugs, may also exert their effect when bound to human PPAR $\gamma$ [26]. Importantly, several environmental contaminants, such as phthalates, perfluorinated compounds and halogenated derivatives of bisphenol A have been shown to activate both human and Danio rerio (zebrafish) PPAR $\gamma$, disrupting lipid homeostasis [27-29]. The antifouling tributyltin (TBT), also shown to interfere with lipid metabolism, presents an additional scenario; while serving as partial agonist to most vertebrate PPAR $\gamma$, it was suggested to exert no activation effect in the teleost PPAR $\gamma$ s tested so far (i.e., Pleuronectes platessa (European plaice), D. rerio (zebrafish), or Pantodon buchholzi (butterflyfish) [6,30,31].

In the present work, we provide an exhaustive examination of PPAR $\gamma$ gene repertoire in different teleost fish species. Through comparative genomic and phylogenetic analyses, we show that the PPAR $\gamma$ gene duplicated in the ancestor of teleosts, and that both paralogues were retained in Salmoniformes, Clupeiformes, Siluriformes, Characiformes and Esociformes taxa. Furthermore, expression profiles and functional characterization of European sardine's (Sardina pilchardus) PPAR $\gamma A$ and $P P A R \gamma B$ is provided. Despite the differences in $P P A R \gamma A$ and $P P A R \gamma B$ gene expression patterns across several tissues of sardine, similar ligand-binding profiles were found, including activation by TBT, previously unreported within teleosts.

\section{Materials and Methods}

\subsection{Phylogenic Analysis}

A phylogenetic analysis was performed to establish the orthology of novel PPAR $\gamma$ sequences. Amino acid sequences from teleosts belonging to several taxonomic orders were collected from GenBank and Ensembl. In addition, PPAR $\alpha$ and PPAR $\beta$ amino acid sequences of a reptile (Anolis carolinensis), an amphibian (Xenopus tropicalis), two Actinopterigii (D. rerio and Lepisosteus oculatus), a bird (Gallus gallus) and two mammals (Homo sapiens and Mus musculus) were used to root the phylogenetic tree. The gathered amino acid sequences were aligned to identify and exclude partial and/or low-quality sequences for further analyses, resulting in a final dataset of 68 PPAR amino acid sequences (accession numbers in Table S1). A MAFFT alignment was generated using MPI Bioinformatics Toolkit [32]. Columns containing 50\% gaps were stripped, resulting in a final alignment with 483 positions for phylogenetic analysis. Maximum Likelihood phylogenetic analysis was performed in PhyMl V3.0 [33] using JTT + G + I + F model as the best evolutionary model, as determined by Smart Model Selection (SMS) [34]. The branch support for the phylogenetic tree was calculated using 1000 bootstraps. The resulting tree was visualized in FigTree V1.3.1 (available at http://tree.bio.ed.ac.uk/software/figtree/, accessed on 15 February 2021).

\subsection{Synteny Analysis}

The genomic regions containing Atlantic herring (Clupea harengus) PPAR $\gamma A$ and $P P A R \gamma B$ genes were localized in the scaffolds NW_012218338.1 (890.5kb) and NW_012221131.1 (264.7kb), respectively. Nine neighboring genes from both sides of these target genes were retrieved from the GenBank database to assemble synteny maps. Atlantic herring loci 
(GCA_000966335.1) were further used as a reference to BLAST against the genome of the remaining 10 species: European sardine (S. pilchardus; GCA_003604335.1), northern pike (Esox lucius; GCA_000721915.3), channel catfish (Ictalurus punctatus; GCA_001660625.2), Mexican tetra (A. mexicanus; GCA_000372685.2), red-bellied piranha (Pygocentrus nattereri; GCA_001682695.1), Atlantic salmon (Salmo salar; GCA_000233375.4), zebrafish (D. rerio; GCA_000002035.4), Amazon molly (Poecilia formosa; GCA_000485575.1), barramundi perch (Lates calcarifer; GCA_001640805.1) and spotted gar (L. oculatus; GCA_000242695.1).

\subsection{Relative Gene Expression Analysis in the European Sardine}

The genome assembly and RNA-Seq datasets of the European sardine [35] were used to determine the relative gene expression (RGE) in various tissues. The S. pilchardus genome (SP_G) assembly and 11 RNA-Seq datasets (spleen, midgut, red muscle, kidney, liver, gonad, head kidney, gill + branchial arch, caudal fin (skin + cartilage + bone), brain + pituitary gland and white muscle) were downloaded from NCBI, while the gtf annotation file was retrieved from ORCAE (https:/ / bioinformatics.psb.ugent.be/gdb/Spil/, accessed on 15 February 2021). The RGE was accessed using a reference-based approach with Hisat2 V.2.2.0 [36] and StringTie V.2.1.2 [37] software. Briefly, the PPAR $\gamma A$ (Spil_000003g0143.1) and PPAR $\gamma B$ (Spil_000027g0044.1) genes were identified via blast in the ORCAE database (https:/ / bioinformatics.psb.ugent.be/orcae/overview/Spil, accessed on 22 February 2021). Next, Hisat2 was used to align the RNA-Seq datasets to the genome, and StringTie was used to perform gene abundance quantification, under the defaults, following the protocol of [38]. Gene abundance was quantified in transcript per million (TPM). TPM values were them Log 2-transformed after adding a value of one $(\log 2(\mathrm{TPM}+1))$.

\subsection{Isolation and Cloning of PPAR $\gamma$ Gene Paralogues of the European Sardine}

Liver tissue from a single specimen of European sardine was collected and preserved in RNAlater at $-20^{\circ} \mathrm{C}$. Total RNA was then extracted using Illustra RNAspin Mini RNA Isolation Kit (GE Healthcare, Chicago, IL, USA), following manufacturer's instructions. Isolated RNA was treated with RNase-free DNase I and eluted with RNase-free water. After RNA quality and quantity assessment using a microplate spectrophotometer (Take 3 and Synergy HT Multi-Mode Microplate Reader, Biotek, Agilent, Santa Clara, CA, USA), $500 \mathrm{ng}$ of liver RNA was used for cDNA synthesis with iScript ${ }^{\mathrm{TM}}$ cDNA Synthesis Kit (Bio-Rad, Hercules, CA, USA), considering the manufacturer's recommendations.

Two gene sequences of PPAR $\gamma$-like were identified in a liver transcriptome dataset of S. pilchardus [39]. Two sets of specific primers, including regions for XbaI and KpnI restriction enzymes, were designed to isolate the ligand binding domain (LBD) of both paralogous genes in sardine. Phusion Flash PCR Master Mix (Thermo Fisher Scientific, Waltham, MA, USA) and specific primer pairs (PPAR $\gamma$ A Fw-5' TTAATCTAGATTGGCGGAGGTCTCGG 3' and PPAR $\gamma$ A Rv-5' GAGCGGTACCCTAGTACAAGTCTCTGATGATC 3'; PPAR $\gamma$ B Fw—5' AAATTCTAGACTGGGTGAAATTGCCAGG 3' and PPAR $\gamma \mathrm{B} \mathrm{Rv-5'}$ AAATGGTACCCTAGTAGAGGTCCCTCATGA 3') were then used in a polymerase chain reaction (PCR) that comprised an initial step at $98{ }^{\circ} \mathrm{C}$ for $10 \mathrm{~s}$ followed by 40 cycles at $98^{\circ} \mathrm{C}$ for $1 \mathrm{~s}, 58^{\circ} \mathrm{C}(\operatorname{PPAR} \gamma \mathrm{A})$ or $56^{\circ} \mathrm{C}(\mathrm{PPAR} \gamma \mathrm{B})$ for $5 \mathrm{~s}$, and $72{ }^{\circ} \mathrm{C}$ for $15 \mathrm{~s}$, with a final extension step for $60 \mathrm{~s}$. At the end, PCR products were loaded onto a $2 \%$ agarose gel, stained with GelRed, and those corresponding to the predicted size were cut and purified with NZYGelpure kit (NZYTech, Lisbon, Portugal).

PCR products and the cloning vector pBIND (AF264722; Promega, Madison, WI, USA) were then digested with $\mathrm{XbaI}$ and $\mathrm{KpnI}$ (NZYTech) and ligated with T4 ligase (Promega) to produce two GAL4 DBD/PPAR $\gamma$ LBD hybrid proteins, one for each sardine PPAR $\gamma$ gene sequence, featuring the DNA binding domain (DBD) of GAL4 and the LBD of one of the $P P A R \gamma$ paralogues. The produced hybrid protein will conditionally bind to the upstream activation sequences (UAS) of a second experimental vector containing a luciferase reporter gene (pGL4.31; DQ487213). Besides the hybrid protein, the pBIND vector also expresses 
Renilla luciferase, used to normalize firefly luciferase activity. The plasmid sequences were confirmed by Sanger sequencing (Eurofins Genomics, Ebersberg, Germany).

\subsection{Cell Culture and In Vitro Transactivation Assays}

COS-1 cells were cultured in DMEM with phenol red (PAN-Biotec, Aidenbach, Germany), supplemented with $10 \%$ fetal bovine serum (PAN-Biotec) and $1 \%$ penicillin/streptomycin (PAN-Biotec), and maintained at $37^{\circ} \mathrm{C}$ in a humidified atmosphere with $5 \% \mathrm{CO}_{2}$.

For luciferase-based reporter transactivation assays, COS-1 cells were seeded $24 \mathrm{~h}$ before transfection in 24-well culture plates at a density of $2 \times 10^{5}$ live cells $/ \mathrm{mL}$ in DMEM with phenol red supplemented as described before. The next day, cells were transfected with $500 \mathrm{ng}$ of pBIND and $1000 \mathrm{ng}$ of pGL4.31, using Lipofectamine 2000 reagent (Thermo Fisher Scientific), in Opti-MEM reduced-serum medium (Gibco, Carlsbad, CA, USA), following the manufacturer's instructions. After $5 \mathrm{~h}$ of incubation, transfection medium was removed and cells were exposed to $1 \mathrm{~mL}$ of DMEM without phenol red (PAN-Biotec), previously supplemented with $10 \%$ of charcoal-treated fetal bovine serum (PAN-Biotec) and $1 \%$ of penicillin/streptomycin, containing $1 \mu \mathrm{L}$ of each test compound (explained in detail below). Dimethyl sulfoxide (DMSO; Sigma-Aldrich, St. Louis, MO, USA) was used as solvent control, at a final concentration of $0.1 \%$ per well. After $24 \mathrm{~h}$ of exposure, cells were lysed and firefly luciferase (pGL4.31) and Renilla luciferase (pBIND) activities were determined using a Dual Luciferase Assay System kit (Promega, Madison, WI, USA), considering manufacturer's recommendations, in a Synergy HT Multi-Mode Microplate Reader.

All assays were repeated three times independently, with two technical replicates per condition being performed each time. Beyond the European sardine PPAR $\gamma \mathrm{A}$ and PPAR $\gamma \mathrm{B}$, these assays were also performed with human PPAR $\gamma$ (kindly provided by Ana Capitão) for comparison purposes, and to guarantee the reliability of the results.

\subsection{Chemicals and Solutions for the In Vitro Experiments}

COS-1 cells were exposed to three different concentrations of PPAR $\gamma$ agonist tributyltin chloride (TBT: 10, 100 and $250 \mathrm{nM}$; Sigma-Aldrich, St. Louis, MO, USA); to rosiglitazone

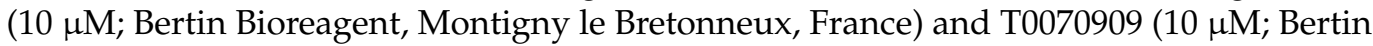
Bioreagent, Montigny le Bretonneux, France), human PPAR $\gamma$ agonist and antagonist, respectively; and to fatty acids (FA; Sigma-Aldrich, St. Louis, MO, USA), arachidonic acid (ARA, $200 \mu \mathrm{M}$ ), docosahexaenoic acid (DHA, $200 \mu \mathrm{M}$ ) and eicosapentaenoic acid (EPA, $200 \mu \mathrm{M}$ ). Two dilutions (50\% and $25 \%$ ) of a mixture composed of seven FAs (FA mix; $42.9 \mathrm{mM}$ ARA, $42.9 \mathrm{mM}$ EPA, $42.9 \mathrm{mM}$ DHA, $42.9 \mathrm{mM}$ oleic acid, $42.9 \mathrm{mM}$ ALA, $42.9 \mathrm{mM}$ $\gamma$-linolenic acid and $11.4 \mathrm{mM}$ palmitic acid) were also tested. All the stock solutions and respective dilutions were prepared in DMSO, with its final concentration being $0.1 \%$ in each well.

\subsection{Statistical Analysis}

To determine the statistical significance of the transactivation results, firefly luciferase activity (reported by pGL4.31) was first normalized using Renilla luciferase activity (internal control for transfection efficiency expressed by pBIND). Final results were presented as fold-induction variations with respect to the solvent control (DMSO). Normalized values of the different replicates were $\operatorname{Ln}(\log$ e)-transformed, and a one-way ANOVA followed by Tukey's post hoc test were performed, using Sigma Stat (version 11, SPSS Inc.), to compare the results. A $p$-value $(p) \leq 0.05$ was considered statistically significant. Results are presented as mean \pm standard error of the mean (SEM).

\subsection{Homology Modelling}

The tridimensional models of the LBD of the European sardine PPAR $\gamma \mathrm{A}$ and PPAR $\gamma \mathrm{B}$ were deduced using a Swiss-Model homology modelling workspace in alignment mode [40,41]. Human PPAR $\gamma$ crystal structure $3 \mathrm{WJ} 4$ was selected as the scaffold template. The quality of the obtained protein structure model was estimated using sequence identity, GMQE 
(global model quality estimation) and QMEAN (qualitative model energy analysis) [42,43]. Models were visualized, inspected, and aligned to human crystal structure 3WJ4 in PyMOL v1.74 [44].

\section{Results}

\subsection{Phylogenetic and Synteny Analyses}

The Maximum Likelihood phylogenetic analysis (Figure 1) performed with 53 PPAR $\gamma$ sequences, 7 PPAR $\alpha$ sequences and 8 PPAR $\beta$, revealed two different PPAR $\gamma$ clades: one including mammal, bird, reptile and amphibian PPAR $\gamma$ genes, and the other containing fish PPAR $\gamma$ s. In the fish PPAR $\gamma$ group, the non-teleost fish spotted gar (L. oculatus) branched off from the teleost PPAR $\gamma$ clade. In agreement with the 3R WGD (third Round of WholeGenome Duplication), two branches diverged in the teleost PPAR $\gamma$ group, corresponding to the PPAR $\gamma$ gene duplication in the last common ancestor of teleosts. Hence, both PPAR $\gamma A$ and $P P A R \gamma B$ paralogous genes are identified in some teleost orders, namely, Salmoniformes (Oncorhynchus mykiss, Oncorhynchus kisutch and S. salar), Clupeiformes (C. harengus and S. pilchardus), Siluriformes (I. punctatus), Characiformes (A. mexicanus and P. nattereri) and Esociformes (E. lucius). Furthermore, duplicate PPAR $\gamma B$ genes (PPAR $\gamma B 1$ and PPAR $\gamma B 2)$ were observed in the salmonids as result of the salmonid-specific fourth round (4R) of WGD (Figure 1).

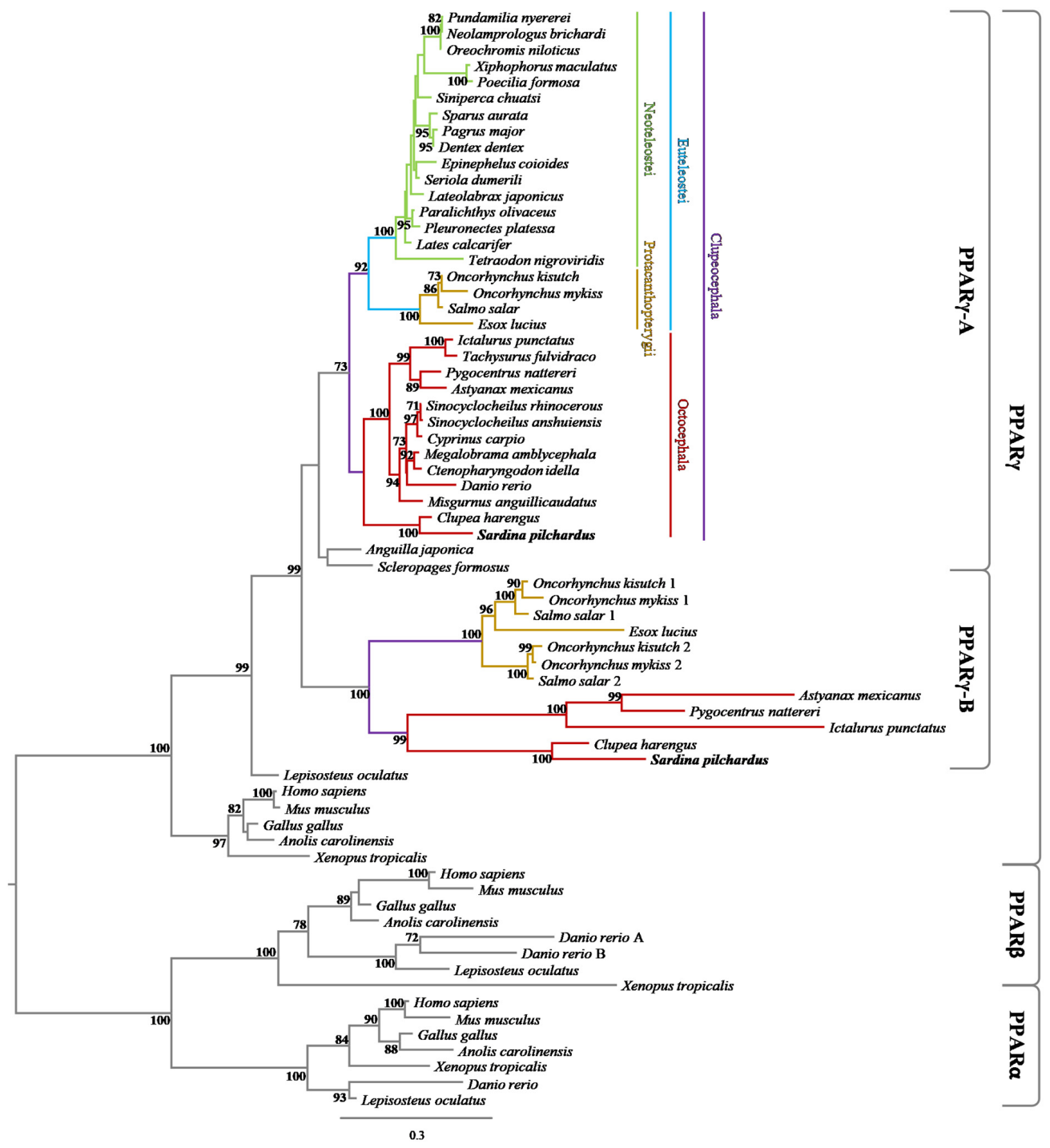

Figure 1. Maximum likelihood phylogenetic analysis of $P P A R \gamma A$ and $P P A R \gamma B$ paralogous genes. The numbers at the nodes indicate bootstrap support values. 
The retention or loss of $P P A R \gamma$ paralogous genes was also confirmed by examining $P P A R \gamma A$ and PPAR $\gamma B$ loci composition and neighborhood in 10 teleosts and in a nonteleost (L. oculatus) fish species (Figure 2). Synteny analysis showed that PPAR $\gamma A$ and $P P A R \gamma B$ neighboring genes are mostly conserved, even in teleosts retaining a single PPAR $\gamma$ paralogous copy (Figure 2).

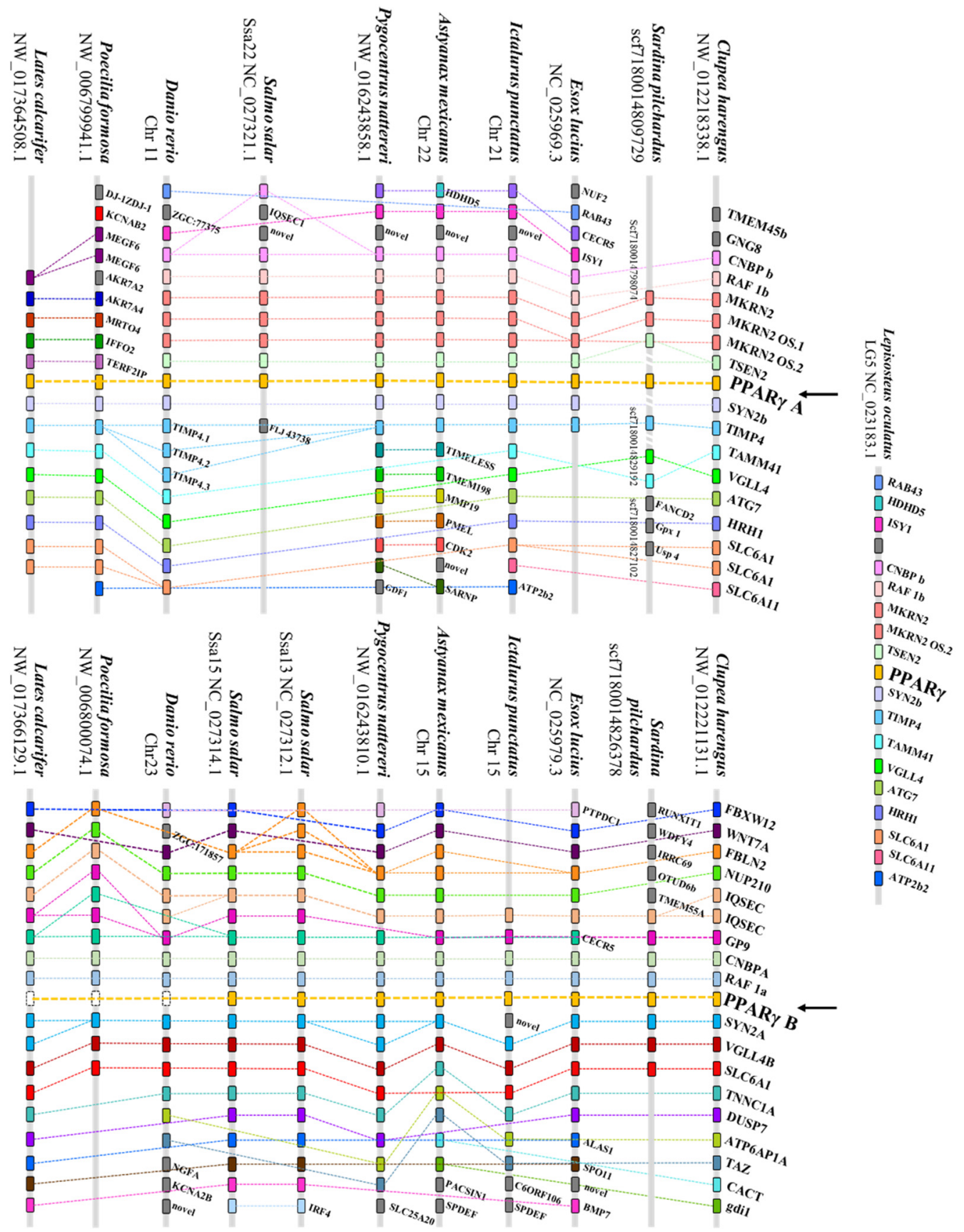

Figure 2. Synteny maps of $P P A R \gamma A$ and PPAR $\gamma B$ loci in representative ray-finned fish species, namely the teleosts Atlantic herring (Clupea harengus), common European sardine (Sardina pilchardus), northern pike (Esox lucius), channel catfish (Ictalurus punctatus), Mexican tetra (Astyanax mexicanus), red-bellied piranha (Pygocentrus nattereri), Atlantic salmon (Salmo salar), zebrafish (Danio rerio), Amazon molly (Poecilia formosa) and barramundi perch (Lates calcarifer). Beyond these, the synteny map of the nonteleost spotted gar (Lepisosteus oculatus) PPAR $\gamma$ loci is also presented. Legend: white box with dashed limit means that gene was lost. 


\subsection{Relative Gene Expression Analysis}

We next examined the relative gene expression (RGE) of the two PPAR $\gamma$ paralogues using the European sardine as a model. RGE analysis was performed using 11 tissues (Figure 3). Our analysis shows that PPAR $\gamma A$ is ubiquitously expressed in all tested tissues, contrarily to $P P A R \gamma B$ that showed higher expression in midgut, liver and head kidney, and residual expression in kidney, brain and pituitary gland and white muscle. No PPAR $\beta B$ expression was observed in spleen, red muscle, gonad, gills and branchial arches or caudal fin tissues. In general, the comparison of RGE among tissues, especially in kidney and brain and pituitary gland, suggests higher expression levels of $P P A R \gamma A$ than $P P A R \gamma B$. However, in liver, head kidney and white muscle, both paralogues presented similar gene expression (Figure 3 and Table S2).
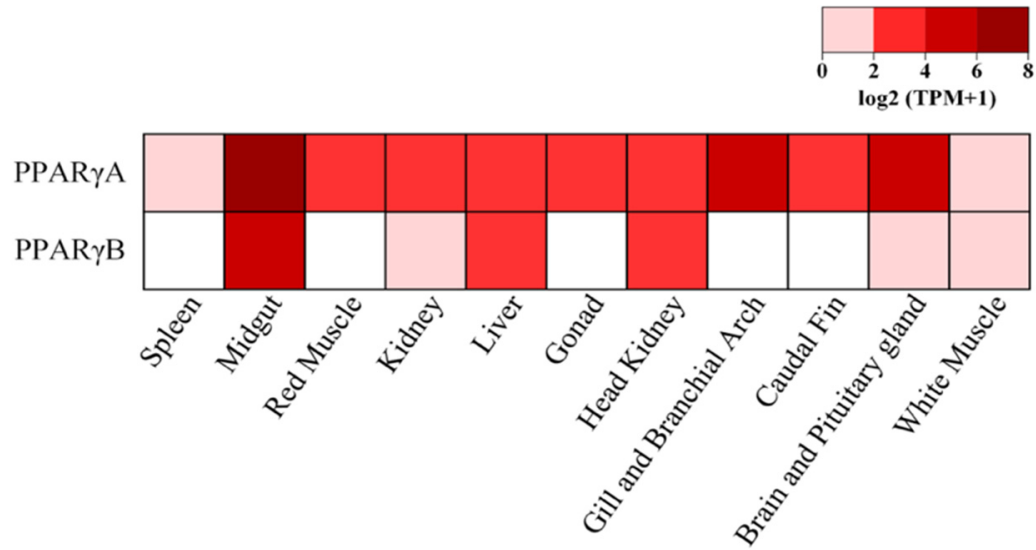

Figure 3. Relative gene expression patterns of common European sardine PPAR $\gamma A$ and $P P A R \gamma B$ genes in 11 tissues. Relative gene expression levels are provided as Log 2-transformed transcript per million (TPM) adding a value of one $[\log 2(\mathrm{TPM}+1)]$, from 0 to 8 .

\subsection{Transactivation Assays}

We next examined the ligand binding profile of European sardine PPAR $\gamma \mathrm{A}$ and PPAR $\gamma$ B in the presence of proposed PPAR $\gamma$ ligands (Figure 4). Tributyltin (TBT), a known obesogen shown to bind to several vertebrate PPAR $\gamma$ receptors, excluding teleosts $[6,30]$, significantly activated both sardine PPAR $\gamma$ receptors when compared to the solvent control (DMSO), except at the lowest TBT concentration $(10 \mathrm{nM})$. Regarding polyunsaturated FAs $(200 \mu \mathrm{M})$ and FAs mixtures (50\% and $25 \%$ diluted), no significant activation or repression of European sardine PPAR $\gamma$ paralogues was detected when compared to the solvent control. Similarly to FAs, neither rosiglitazone nor T0070909 $(10 \mu \mathrm{M})$, agonist and antagonist of the human PPAR $\gamma$, respectively, had a significant effect on the European sardine PPAR $\gamma$ A or PPAR $\gamma$ B modulation (Figure 4) relative to the DMSO. The human PPAR $\gamma$ LBD, used as control, was significantly activated by TBT (100 and $250 \mathrm{nM})$, FAs $(200 \mu \mathrm{M}$ and $50 \%$ and $25 \%$ dilution mixes) and rosiglitazone $(10 \mu \mathrm{M})$, and repressed by T0070909 $(10 \mu \mathrm{M})$, as previously described (Figure S1).

\subsection{Sequence Analysis and Homology Modelling}

To further address the TBT activation profile, previously unreported in teleost fish, we deduced European sardine PPAR $\gamma \mathrm{A}$ and PPAR $\gamma \mathrm{B}$ tridimensional structures and examined the conservation of LBD residues reported to interact with TBT, through structural and sequence alignment, using the human PPAR $\gamma$ crystal structure (3WJ4) as a template (Figure 5). Overall, the TBT-interacting amino acid composition of the teleost sequences are poorly conserved, as previously reported for D. rerio (zebrafish) and P. buchholzi (butterflyfish) [6]. The observed substitutions occur between amino acids with hydrophobic side chains, yet an increase in aromatic ring content is also noted, with smaller hydrophobic amino acids replaced by residues with aromatic hydrophobic side chains (Phe, Trp, or Tyr). While these substitutions maintain the hydrophobic core of the binding pocket, they impose distinct 
spatial and volume constraints within the binding cavity. For instance, as previously noted, Cys285Tyr replacement in zebrafish and butterflyfish leads to an aromatic ring protrusion into the pocket [6], similar to the Cys285Phe and Leu330Trp substitutions observed in European sardine PPAR $\gamma \mathrm{A}$ and PPAR $\gamma \mathrm{B}$, respectively. More specifically, we examined the conservation status of a signature cysteine in helix 3 (Cys285, H3), with a sulfur-containing side chain shown to bind to the tin atom of TBT [45]. Curiously, this residue, critical for TBT-induced activation in other non-teleost species, is not conserved in the TBT-responsive European sardine PPAR $\gamma$ A and PPAR $\gamma B$ [6]. Despite the absence of a Cys residue in H3, additional sulfur-containing amino acids are overserved in the $\beta$-strand $\mathrm{B} 3$ of European sardine PPAR $\gamma \mathrm{A}$ and PPAR $\gamma \mathrm{B}$ (Met and Cys, respectively), but not in zebrafish. In the human PPAR $\gamma$, TBT partial agonist activity was suggested to derive predominantly from interactions with residues in $\mathrm{H} 3$ and $\mathrm{B} 3$ [45].

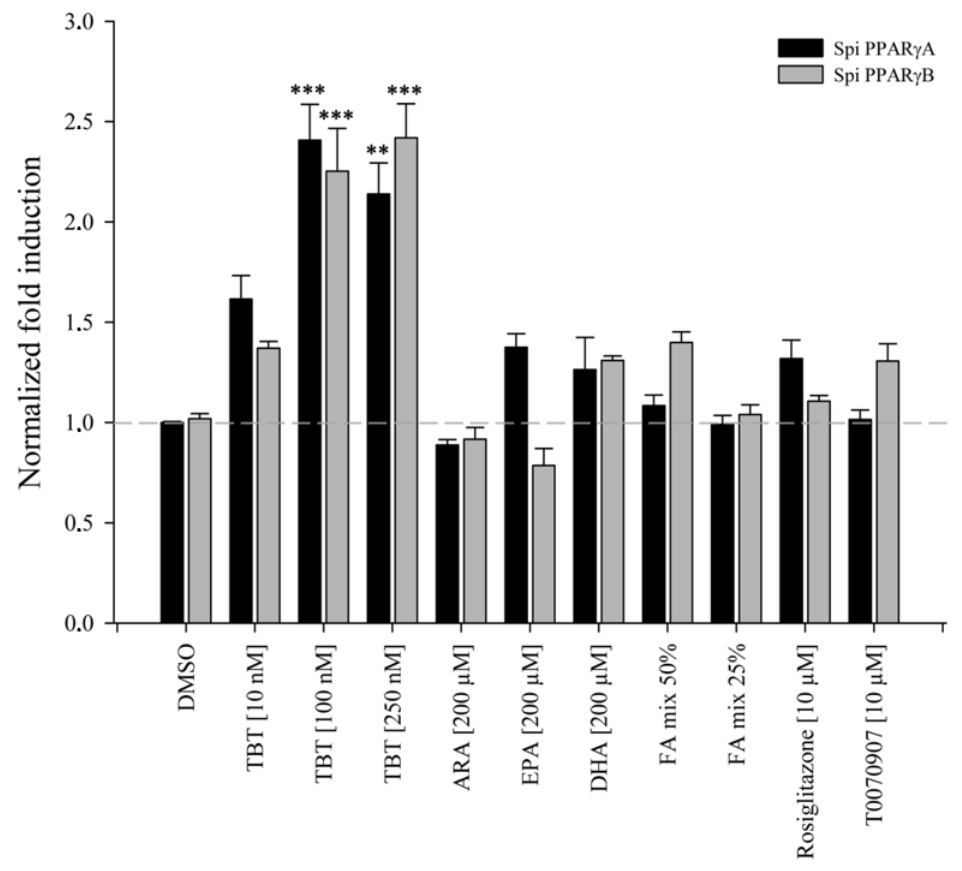

Figure 4. Results of transactivation assays with European sardine PPAR $\gamma \mathrm{A}$ and PPAR $\gamma \mathrm{B}$. In these assays, transiently transfected COS-1 cells were exposed to three concentrations of tributyltin chloride (TBT; $10 \mathrm{nM}, 100 \mathrm{nM}$ and $250 \mathrm{nM}$ ), two concentrations of a mixture of seven fatty acids (FA mix; 50\% and $25 \%$ ) and one concentration of arachidonic acid (ARA, $200 \mu \mathrm{M})$, eicosapentaenoic acid (EPA, $200 \mu \mathrm{M}$ ), docosahexaenoic acid (DHA, $200 \mu \mathrm{M}$ ), rosiglitazone (human PPAR $\gamma$ agonist; $10 \mu \mathrm{M}$ ) and T0070909 (human PPAR $\gamma$ antagonist; $10 \mu \mathrm{M}$ ). Dimethyl sulfoxide (DMSO; 0.1\%) was used as solvent control. Data are shown as mean \pm standard error of the mean (SEM). Legend: ${ }^{* *}$ and ${ }^{* * *}$ shows a statistically significant response of $p \leq 0.01$ and $p \leq 0.001$, respectively, when compared to DMSO. 
A
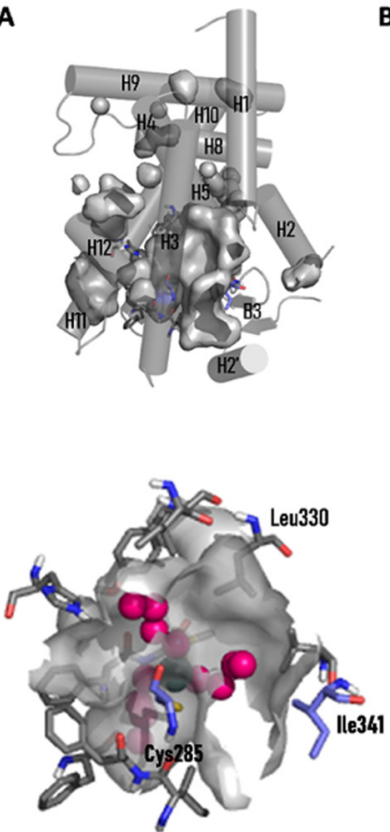
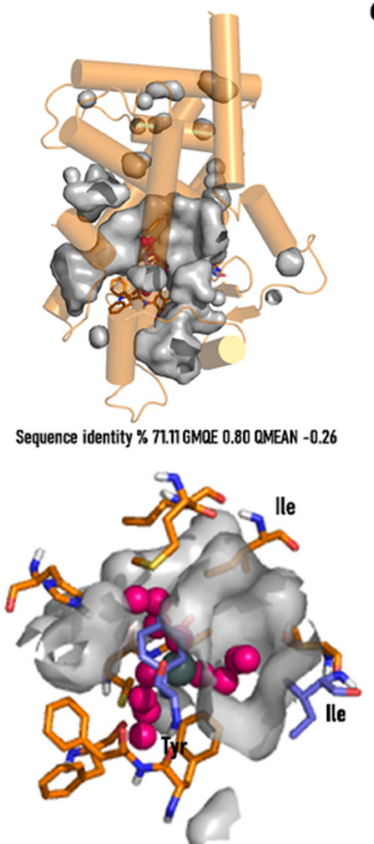

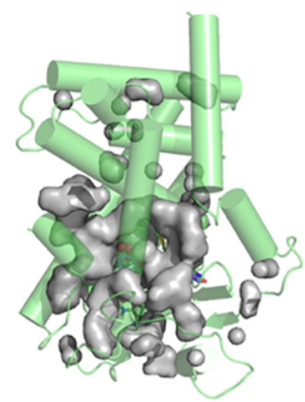

Sequence identity $68.27 \%$ I GMaE 0.77 । I MEEN - 0.10

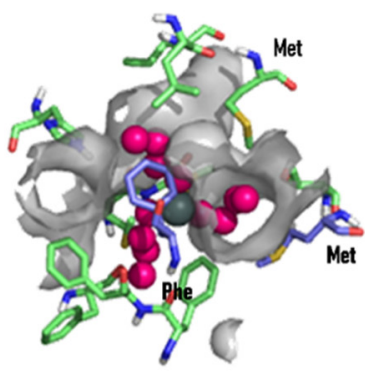

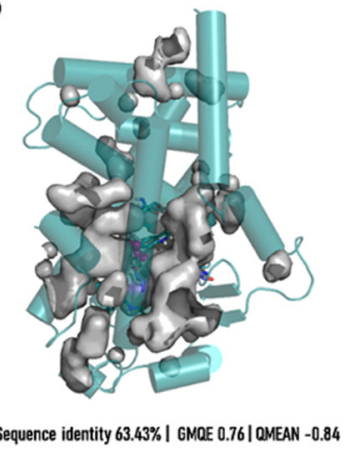

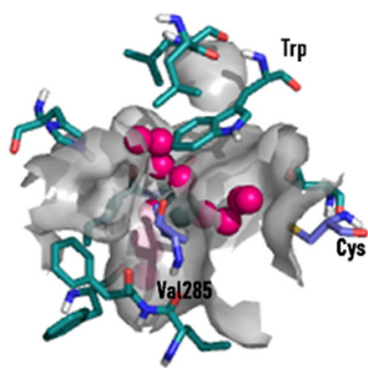

E

H3

H5

B3

H7

H11

\begin{tabular}{|c|c|c|c|c|c|c|c|c|c|c|c|c|}
\hline Human & |le281 & Phe282 & Cys285 & Ile326 & Tyr327 & Leu330* & Val339 & Ile341 & Phe 360 & Phe363 & Met364 & His 449 \\
\hline Zebrafish & Phe & . & Tyr & Met & Mle & Ile & Thr & . & - & Met & - & . \\
\hline Sardine A & Phe & . & Phe & Lew & lite & Met & Thr & Met & . & Met & . & . \\
\hline Sardine B & Leu & . & Val & Leu & Leu & Trp & Thr & Cys & . & 116 & Leu & . \\
\hline
\end{tabular}

Figure 5. PPAR $\gamma$ ligand-binding pocket (LBP) cavities analysis. (A) Human PPAR $\gamma$ ligand-binding domain (LBD) crystal structure 3WJ4 with representation of LBD cavities (top), and detailed view of the LBP cavity with the residues that interact with TBT (Harada et al. 2015 [45]) depicted as sticks (down). (B-D) Zebrafish PPAR $\gamma$, sardine PPAR $\gamma$ A and sardine PPAR $\gamma$ B homology models with representation of LBD cavities (top), and detailed view of the LBP cavities with the corresponding interacting residues depicted as sticks (down). TBT molecule from crystal structure 3WJ4 is shown in magenta. Sequence identity (\%), global model quality estimation (GMQE), QMean are indicated below each model. (E) Human PPAR $\gamma$ residues that interact with TBT and the corresponding residues found in Zebrafish PPAR $\gamma$, sardine PPAR $\gamma \mathrm{A}$ and sardine PPAR $\gamma \mathrm{B}$. The location of the residues in the structure is indicated $\left(\mathrm{H}\right.$, helix; $\mathrm{B}, \beta$-strand). ${ }^{*}$ Indicates a residue substitution in sardine PPAR $\gamma \mathrm{B}$, resulting in an aromatic ring protrusion.

\section{Discussion}

During the evolution of vertebrates, polyploidization events have been proposed to provide the new genetic material for the emergence of novelties [46-51]. Although the exact duplication timings have fueled intense debate, the current consensus suggests one shared genome duplication (1R; first Round) between cyclostomes and gnathostomes, with independent duplication taking place in each lineage independently [52]. In teleosts, a 3R WGD (Whole-Genome Duplication) is proposed at the origin of teleosts [53]. Besides this last WGD, a 4R WGD was inferred in salmonids [53-56]. In the context of NR (Nuclear Receptor) gene evolution, WGD occurrences have been central components. Recently, Capitão and collaborators [6] suggested that PPAR-like sequences present in all vertebrate lineages result from WGD events that occurred before gnathostome radiation and after tunicate divergence, yielding the three PPAR paralogous genes. The consequences of the 3R WGD on PPAR gene numbers has also been previously established for both PPAR $\alpha$ and PPAR $\beta$ genes [8,11,57-61]. Recently, Wafer and collaborators [13] identified two PPAR $\gamma$ paralogous genes in Mexican tetra (A. mexicanus), suggesting a pronounced loss of duplicated PPAR $\gamma$ 
in other teleost lineages. In the present work, by means of comparative genomics and phylogenetic analyses, we investigate the presence of $P P A R \gamma$ paralogous genes in an ample collection of ray-finned fish lineages. As expected, spotted gar (L. oculatus) presented a single PPAR $\gamma$ copy, since this species diverged prior to the 3R WGD event (Figures 1 and 2). Moreover, our analyses showed that two PPAR $\gamma$ paralogous genes (Figure 2) were retained not only in Characiformes (tetras and piranhas), but also in Salmoniformes (salmons and trouts), Clupeiformes (herrings and sardines), Siluriformes (catfishes), and Esociformes (pikes) taxa (Figure 1). These observations suggest a wider retention of PPAR $\gamma$ paralogues than previously anticipated [13]. Additional salmonid-specific PPAR $\gamma \mathrm{B}$ duplicates were found in Atlantic salmon (S. salar), coho salmon (O. kisutch) and rainbow trout (O. mykiss), which resulted of the $4 \mathrm{R}$ WGD. The presence of both $P P A R \gamma$ paralogues in such lineages and the retention of a single $P P A R \gamma$ paralogue in the early-diverging teleost lineages such as Elopomorpha (e.g., eels) and Osteoglossomorpha (e.g., butterflyfishes), allows us to estimate that the retention of $P P A R \gamma$ duplicated genes occurred at the time of Clupeocephala divergence, approximately 185-190 Million years ago [62]. Thus, similarly to PPAR $\alpha$ and $P P A R \beta, P P A R \gamma$ duplication resulted from 3R WGD, with episodes of gene loss shaping teleost $P P A R \gamma$ gene repertoire.

Human PPARs can be activated by both saturated and unsaturated dietary FAs, as well as lipids involved in intracellular signaling pathways [63-65]. When binding to these ligands, PPARs play an important physiological role, with PPAR $\gamma$ being crucial for lipid storage and adipogenesis [66]. To determine the binding profile of European sardine's PPAR $\gamma$ A and PPAR $\gamma B$, we assessed the ability of transiently transfected mammalian cells to induce reporter gene transcription upon exposure to ligands able to bind and modulate human PPAR $\gamma$ (see Figure S1). Regarding FAs, no significant responses were observed with the European sardine $P P A R \gamma$ paralogues. This agrees with previous reports with plaice (P. platessa) and gilthead sea bream (Sparus aurata) PPAR $\gamma \mathrm{s}$, also yielding no activation upon exposure to FAs [57]. In the chondrichthyan Leucoraja erinacea (little skate) on the other hand, FAs were shown to be potent inducers of PPAR $\gamma$ [6]. These disparate observations could be due to structural constraints in the binding cavity of teleost PPAR $\gamma \mathrm{s}$. In fact, the deduced tridimensional structures of the European sardine, zebrafish and butterflyfish PPAR $\gamma$ s show low residue conservation, displaying more amino acid residues with bulky aromatic side chains possibly affecting pocket size and architecture, whereas the little skate binding pocket is highly conserved when compared to human PPAR $\gamma$ [6]. Null activation profiles were obtained with the synthetic PPAR $\gamma$ agonist and antagonists, in agreement with previous reports on the modulation of zebrafish PPAR $\gamma$ by rosiglitazone [27]. Sardine PPAR $\gamma$ paralogues were also tested for their susceptibility towards TBT (tributyltin) binding. TBT is a currently restricted organotin compound, long used as an antifouling agent in general maritime industries [67-69]. In aquatic environments, exposure to TBT mediates endocrine disruption, causing an abnormal induction of male sex characters in females in gastropod mollusks $[70,71]$ and fishes $[72,73]$. TBT is also considered an obesogen since it is able to bind and greatly induce PPAR $\gamma$ activity, disturbing lipid and energy metabolism in some vertebrates $[6,74,75]$. Crystallographic analysis of human PPAR $\gamma$ bound to TBT unraveled a partial agonist binding mode, with the ligand TBT interacting with a sulfur-containing cysteine residue (Cys285) on helix 3 (H3) and establishing hydrophobic interactions with the side chains of two residues (Val339 and Ile341) embedded on the $\beta$-strand (B3), inducing conformational changes that allow cofactor binding and transcription [45]. Cysteine residues have been shown to be crucial for the anchorage of TBT, not only in PPARs but also in the Retinoid X Receptor (RXR), through interaction of the tin atom with the highly reactive sulfhydryl group of the cysteine side chain $[45,76]$. In agreement, teleost PPAR $\gamma$ s lacking such signature cysteine (e.g., plaice, zebrafish or butterflyfish) were shown to be unresponsive towards growing concentrations of TBT [6,30]. Furthermore, the substitution of the cysteine residue in human and little skate PPAR $\gamma \mathrm{s}$ abolished TBT-mediated reporter gene transcription in vitro [6,45]. Yet, both European sardine PPAR $\gamma \mathrm{A}$ and PPAR $\gamma \mathrm{B}$ were able to induce reporter gene transcription upon TBT 
exposure, despite lacking the conserved cysteine in H3 (Figures 4 and 5). This observation challenges the universality of the TBT-dependent PPAR $\gamma$ activation mechanism. Careful analysis of pocket residue composition highlights possible alternatives. In fact, sardine PPAR $\gamma$ B exhibits an available cysteine residue in B3 to anchor TBT, whereas PPAR $\gamma$ A has a methionine. Similarly to cysteine, methionine is a sulfur-containing amino acid, and despite its lower reactivity could also react with the tin atom [77]. In spite of the consensus on the crucial role of cysteine for TBT binding, unusual binding modes have been previously observed. For instance, in the Echinodermata Paracentrotus lividus, PPAR $\gamma$ is unresponsive to TBT despite the conservation of H3 cysteine, whereas the cysteine-to-tyrosine substitutions observed in teleosts such as zebrafish and in the mollusk Patella depressa yield null or repressive responses, respectively [4-6]. Alternative modes for TBT binding have also been proposed for RXR [78]. Thus, future structural studies should address these potential alternative binding architectures.

Although no differences were found in the ligand-binding profile of sardine PPAR $\gamma \mathrm{A}$ and PPAR $\gamma \mathrm{B}$, relative gene expression analysis shows a distinct tissue distribution pattern, with the European sardine PPAR $\gamma A$ displaying ubiquitous expression in all analyzed tissues, whereas $P P A R \gamma B$ is only expressed in midgut, kidney, liver, head kidney, brain and pituitary gland, and white muscle (Figure 3 and Table S2). In mammals, PPAR $\gamma$ expression is detected in the gastrointestinal tract (only during embryonic development), liver, kidney, heart, adipose tissues, skeletal muscle, placenta and lung. Further promoter usage and alternative splicing lead to the differential expression of PPAR $\gamma$ splice variants in each of these tissues reviewed in $[3,79,80]$. Thus, the retention of both PPAR $\gamma$ genes in various teleost lineages could be related, with a distinct spatial and temporal distribution.

\section{Conclusions}

In conclusion, this study indicates that $3 R$ WGD led to $P P A R \gamma$ gene duplication, as previously described for PPAR $\alpha$ and $P P A R \beta$ paralogues. PPAR $\gamma$ paralogue retention was first reported in A. mexicanus (Characiformes), however, we suggest that PPAR $\gamma$ paralogue retention affected many other teleost lineages. In spite of the differential tissue distributions and expression patterns of sardine PPAR $\gamma \mathrm{A}$ and $P P A R \gamma \mathrm{B}$, indicating tissue-specific functions, both PPAR $\gamma$ genes presented similar ligand preferences. Nevertheless, the modulation of sardine PPAR $\gamma$ paralogues by TBT challenges current paradigms and emphasizes the need to further address the mechanisms of ligand-binding and the susceptibility of teleost lineages towards organotin exposure.

Supplementary Materials: The following are available online at https:/ / www.mdpi.com/article / 10.3390/genes13010107/s1, Figure S1: In vitro transcriptional activation of Homo sapiens PPAR $\gamma$, Table S1: Accession numbers of the sequences used to perform the phylogenic analysis, Table S2: Relative gene expression levels of $P P A R \gamma A$ and $P P A R \gamma B$ in Sardina pilchardus.

Author Contributions: Conceptualization, I.C., L.F.C.C.; methodology, I.P., E.F., A.M.M., F.C., R.R., L.F.C.C.; software, A.M.M.; validation, I.P., E.F., R.R.; formal analysis, I.P., E.F., R.R., A.M.M., F.C.; investigation, I.P., E.F., R.F., A.M.M., F.C.; resources, I.C., L.F.C.C.; data curation, E.F., A.M.M., F.C.; writing-original draft preparation, I.P., E.F., A.M.M.; writing-review and editing, R.F., F.C., R.R., I.C., L.F.C.C.; visualization, I.P., E.F., R.R., L.F.C.C.; supervision, I.C., L.F.C.C.; project administration, I.C., L.F.C.C.; funding acquisition, I.C., L.F.C.C. All authors have read and agreed to the published version of the manuscript.

Funding: This research was funded by FCT-Foundation for Science and Technology (Portugal)under the projects CY-SENSORS (PTDC/BTA-GES/32359/2017), by COMPETE 2020, Portugal 2020, and the European Union through the ERDF, grant number 031342, and by FCT through national funds (PTDC/CTA-AMB/31342/2017), UIDB/04423/2020 and UIDP/04423/2020.

Institutional Review Board Statement: Not applicable.

Informed Consent Statement: Not applicable. 
Data Availability Statement: Data available as supplementary material. Other can be requested from the corresponding authors.

Conflicts of Interest: The authors declare no conflict of interest.

\section{References}

1. Glass, C.K.; Rosenfeld, M.G. The coregulator exchange in transcriptional functions of nuclear receptors. Genes Dev. 2000, 14, 121-141. [CrossRef] [PubMed]

2. $\quad$ Bookout, A.L.; Jeong, Y.; Downes, M.; Yu, R.T.; Evans, R.M.; Mangelsdorf, D.J. Anatomical Profiling of Nuclear Receptor Expression Reveals a Hierarchical Transcriptional Network. Cell 2006, 126, 789-799. [CrossRef] [PubMed]

3. Abbott, B.D. Review of the expression of peroxisome proliferator-activated receptors alpha (PPAR $\alpha)$, beta (PPAR $\beta)$, and gamma (PPAR $\gamma$ ) in rodent and human development. Reprod. Toxicol. 2009, 27, 246-257. [CrossRef] [PubMed]

4. $\quad$ Capitão, A.M.F.; Lopes-Marques, M.; Páscoa, I.; Sainath, S.B.; Hiromori, Y.; Matsumaru, D.; Nakanishi, T.; Ruivo, R.; Santos, M.M.; Castro, L.F.C. An ancestral nuclear receptor couple, PPAR-RXR, is exploited by organotins. Sci. Total Environ. 2021, 797, 149044. [CrossRef]

5. $\quad$ Capitão, A.; Lopes-Marques, M.; Páscoa, I.; Ruivo, R.; Mendiratta, N.; Fonseca, E.; Castro, L.F.C.; Santos, M.M. The Echinodermata PPAR: Functional characterization and exploitation by the model lipid homeostasis regulator tributyltin. Environ. Pollut. 2020, 263, 114467. [CrossRef]

6. $\quad$ Capitão, A.M.F.; Lopes-Marques, M.S.; Ishii, Y.; Ruivo, R.; Fonseca, E.S.S.; Páscoa, I.; Jorge, R.P.; Barbosa, M.; Hiromori, Y.; Miyagi, T.; et al. Evolutionary Exploitation of Vertebrate Peroxisome Proliferator-Activated Receptor $\gamma$ by Organotins. Environ. Sci. Technol. 2018, 52, 13951-13959. [CrossRef]

7. Ran, Z.; Kong, F.; Liao, K.; Xu, J.; Liu, X.; Shi, P.; Zhang, M.; Wu, K.; Yan, X. Identification and Expression of PPAR in Sinonovacula constricta and Their Potential Regulatory Effects on $\Delta 6$ Fad Transcription. J. Ocean Univ. China 2021, 20, 1557-1566. [CrossRef]

8. Bertrand, S.; Brunet, F.G.; Escriva, H.; Parmentier, G.; Laudet, V.; Robinson-Rechavi, M. Evolutionary Genomics of Nuclear Receptors: From Twenty-Five Ancestral Genes to Derived Endocrine Systems. Mol. Biol. Evol. 2004, 21, 1923-1937. [CrossRef]

9. Bertrand, S.; Thisse, B.; Tavares, R.; Sachs, L.; Chaumot, A.; Bardet, P.-L.; Escriva, H.; Duffraisse, M.; Marchand, O.; Safi, R.; et al. Unexpected Novel Relational Links Uncovered by Extensive Developmental Profiling of Nuclear Receptor Expression. PLoS Genet. 2007, 3, e188. [CrossRef]

10. Leaver, M.J.; Ezaz, M.T.; Fontagné-Dicharry, S.; Tocher, D.R.; Boukouvala, E.; Krey, G. Multiple peroxisome proliferator-activated receptor $\beta$ subtypes from Atlantic salmon (Salmo salar). J. Mol. Endocrinol. 2007, 38, 391-400. [CrossRef]

11. Madureira, T.V.; Pinheiro, I.; Freire, R.P.; Rocha, E.; Castro, L.F.; Urbatzka, R. Genome specific PPAR $\alpha B$ duplicates in salmonids and insights into estrogenic regulation in brown trout. Comp. Biochem. Physiol. Part B Biochem. Mol. Biol. 2017, 208-209, 94-101. [CrossRef]

12. Schaaf, M.J.M. Nuclear receptor research in zebrafish. J. Mol. Endocrinol. 2017, 59, R65-R76. [CrossRef]

13. Wafer, R.; Tandon, P.; Minchin, J.E.N. The Role of Peroxisome Proliferator-Activated Receptor Gamma (PPARG) in Adipogenesis: Applying Knowledge from the Fish Aquaculture Industry to Biomedical Research. Front. Endocrinol. 2017, 8, 102. [CrossRef]

14. Vidal-Puig, A.J.; Considine, R.V.; Jimenez-Liñan, M.; Werman, A.; Pories, W.J.; Caro, J.F.; Flier, J.S. Peroxisome proliferatoractivated receptor gene expression in human tissues. Effects of obesity, weight loss, and regulation by insulin and glucocorticoids. J. Clin. Investig. 1997, 99, 2416-2422. [CrossRef] [PubMed]

15. Tontonoz, P.; Hu, E.; Spiegelman, B.M. Stimulation of adipogenesis in fibroblasts by PPAR $\gamma 2$, a lipid-activated transcription factor. Cell 1994, 79, 1147-1156. [CrossRef]

16. Den Broeder, M.J.; Moester, M.J.B.; Kamstra, J.H.; Cenijn, P.H.; Davidoiu, V.; Kamminga, L.M.; Ariese, F.; De Boer, J.F.; Legler, J. Altered Adipogenesis in Zebrafish Larvae Following High Fat Diet and Chemical Exposure Is Visualised by Stimulated Raman Scattering Microscopy. Int. J. Mol. Sci. 2017, 18, 894. [CrossRef] [PubMed]

17. Wang, A.; Yang, W.; Liu, F.; Yin, X.; Yu, Y. Peroxisome proliferator-activated receptor gamma (Ppary) in Redlip Mullet Liza haematocheila: Molecular cloning, tissue distribution, and response to dietary lipid levels. Turk. J. Fish Aquat. Sc. 2017, 17, 477-485. [CrossRef]

18. Den Broeder, M.J.; Kopylova, V.A.; Kamminga, L.M.; Legler, J. Zebrafish as a Model to Study the Role of Peroxisome ProliferatingActivated Receptors in Adipogenesis and Obesity. PPAR Res. 2015, 2015, 1-11. [CrossRef]

19. Sundvold, H.; Ruyter, B.; Østbye, T.-K.; Moen, T. Identification of a novel allele of peroxisome proliferator-activated receptor gamma (PPARG) and its association with resistance to Aeromonas salmonicida in Atlantic salmon (Salmo salar). Fish Shellfish. Immunol. 2010, 28, 394-400. [CrossRef]

20. Antonopoulou, E.; Kaitetzidou, E.; Castellana, B.; Panteli, N.; Kyriakis, D.; Vraskou, Y.; Planas, J. In Vivo Effects of Lipopolysaccharide on Peroxisome Proliferator-Activated Receptor Expression in Juvenile Gilthead Seabream (Sparus Aurata). Biology 2017, 6, 36. [CrossRef]

21. Adeogun, A.O.; Ibor, O.R.; Regoli, F.; Arukwe, A. Peroxisome proliferator-activated receptors and biotransformation responses in relation to condition factor and contaminant burden in tilapia species from Ogun River, Nigeria. Comp. Biochem. Physiol. Part $C$ Toxicol. Pharmacol. 2016, 183-184, 7-19. [CrossRef] 
22. Forman, B.M.; Chen, J.; Evans, R.M. Hypolipidemic drugs, polyunsaturated fatty acids, and eicosanoids are ligands for peroxisome proliferator-activated receptors and. Proc. Natl. Acad. Sci. USA 1997, 94, 4312-4317. [CrossRef]

23. Schopfer, F.J.; Lin, Y.; Baker, P.R.S.; Cui, T.; Garcia-Barrio, M.; Zhang, J.; Chen, K.; Chen, Y.E.; Freeman, B.A. Nitrolinoleic acid: An endogenous peroxisome proliferator-activated receptor ligand. Proc. Natl. Acad. Sci. USA 2005, 102, 2340-2345. [CrossRef] [PubMed]

24. Liberato, M.V.; Nascimento, A.S.; Ayers, S.D.; Lin, J.Z.; Cvoro, A.; Silveira, R.L.; Martínez, L.; Souza, P.C.T.; Saidemberg, D.; Deng, T.; et al. Medium Chain Fatty Acids Are Selective Peroxisome Proliferator Activated Receptor (PPAR) $\gamma$ Activators and Pan-PPAR Partial Agonists. PLoS ONE 2012, 7, e36297. [CrossRef] [PubMed]

25. Yang, Z.-H.; Miyahara, H.; Iwasaki, Y.; Takeo, J.; Katayama, M. Dietary supplementation with long-chain monounsaturated fatty acids attenuates obesity-related metabolic dysfunction and increases expression of PPAR gamma in adipose tissue in type 2 diabetic KK-Ay mice. Nutr. Metab. 2013, 10, 16. [CrossRef] [PubMed]

26. Grygiel-Górniak, B. Peroxisome proliferator-activated receptors and their ligands: Nutritional and clinical implications-a review. Nutr. J. 2014, 13, 17. [CrossRef] [PubMed]

27. Riu, A.; Mccollum, C.W.; Pinto, C.L.; Grimaldi, M.; Hillenweck, A.; Perdu, E.; Zalko, D.; Bernard, L.; Laudet, V.; Balaguer, P.; et al. Halogenated Bisphenol-A Analogs Act as Obesogens in Zebrafish Larvae (Danio rerio). Toxicol. Sci. 2014, 139, 48-58. [CrossRef]

28. Grimaldi, M.; Boulahtouf, A.; Delfosse, V.; Thouennon, E.; Bourguet, W.; Balaguer, P. Reporter cell lines to evaluate the selectivity of chemicals for human and zebrafish estrogen and peroxysome proliferator activated $\hat{\mathrm{I}}^{3}$ receptors. Front. Neurosci. 2015, 9, 212. [CrossRef]

29. Huang, Q.; Chen, Q. Mediating Roles of PPARs in the Effects of Environmental Chemicals on Sex Steroids. PPAR Res. 2017, 2017, 3203161. [CrossRef] [PubMed]

30. Colliar, L.; Sturm, A.; Leaver, M.J. Tributyltin is a potent inhibitor of piscine peroxisome proliferator-activated receptor $\alpha$ and $\beta$. Comp. Biochem. Physiol. Part C Toxicol. Pharmacol. 2011, 153, 168-173. [CrossRef]

31. Janesick, A.; Blumberg, B. Minireview: PPAR $\gamma$ as the target of obesogens. J. Steroid Biochem. Mol. Biol. 2011, 127, 4-8. [CrossRef]

32. Zimmermann, L.; Stephens, A.; Nam, S.-Z.; Rau, D.; Kübler, J.; Lozajic, M.; Gabler, F.; Söding, J.; Lupas, A.N.; Alva, V. A Completely Reimplemented MPI Bioinformatics Toolkit with a New HHpred Server at its Core. J. Mol. Biol. 2018, 430, $2237-2243$. [CrossRef]

33. Guindon, S.; Dufayard, J.-F.; Lefort, V.; Anisimova, M.; Hordijk, W.; Gascuel, O. New Algorithms and Methods to Estimate Maximum-Likelihood Phylogenies: Assessing the Performance of PhyML 3.0. Syst. Biol. 2010, 59, 307-321. [CrossRef]

34. Lefort, V.; Longueville, J.-E.; Gascuel, O. SMS: Smart Model Selection in PhyML. Mol. Biol. Evol. 2017, 34, 2422-2424. [CrossRef]

35. Louro, B.; De Moro, G.; Garcia, C.; Cox, C.J.; Veríssimo, A.; Sabatino, S.J.; Santos, A.M.; Canário, A.V.M. A haplotype-resolved draft genome of the European sardine (Sardina pilchardus). GigaScience 2019, 8, giz059. [CrossRef]

36. Kim, D.; Langmead, B.; Salzberg, S.L. HISAT: A fast spliced aligner with low memory requirements. Nat. Methods 2015, 12, 357-360. [CrossRef]

37. Pertea, M.; Pertea, G.M.; Antonescu, C.M.; Chang, T.-C.; Mendell, J.T.; Salzberg, S.L. StringTie enables improved reconstruction of a transcriptome from RNA-seq reads. Nat. Biotechnol. 2015, 33, 290-295. [CrossRef] [PubMed]

38. Pertea, M.; Kim, D.; Pertea, G.M.; Leek, J.T.; Salzberg, S.L. Transcript-level expression analysis of RNA-seq experiments with HISAT, StringTie and Ballgown. Nat. Protoc. 2016, 11, 1650-1667. [CrossRef]

39. Machado, A.M.; Tørresen, O.K.; Kabeya, N.; Couto, A.; Petersen, B.; Felício, M.; Campos, P.F.; Fonseca, E.; Bandarra, N.; Lopes-Marques, M.; et al. "Out of the Can": A Draft Genome Assembly, Liver Transcriptome, and Nutrigenomics of the European Sardine, Sardina pilchardus. Genes 2018, 9, 485. [CrossRef] [PubMed]

40. Arnold, K.; Bordoli, L.; Kopp, J.; Schwede, T. The SWISS-MODEL workspace: A web-based environment for protein structure homology modelling. Bioinformatics 2006, 22, 195-201. [CrossRef] [PubMed]

41. Biasini, M.; Bienert, S.; Waterhouse, A.; Arnold, K.; Studer, G.; Schmidt, T.; Kiefer, F.; Cassarino, T.G.; Bertoni, M.; Bordoli, L.; et al. SWISS-MODEL: Modelling protein tertiary and quaternary structure using evolutionary information. Nucleic Acids Res. 2014, 42, W252-W258. [CrossRef]

42. Benkert, P.; Tosatto, S.C.E.; Schomburg, D. QMEAN: A comprehensive scoring function for model quality assessment. Proteins Struct. Funct. Bioinform. 2008, 71, 261-277. [CrossRef] [PubMed]

43. Benkert, P.; Biasini, M.; Schwede, T. Toward the estimation of the absolute quality of individual protein structure models. Bioinformatics 2011, 27, 343-350. [CrossRef]

44. Schrödinger, L.L.C. The PyMOL Molecular Graphics System, Version 1.3; Schrodinger Sales Center: New York, NY, USA, 2010.

45. Harada, S.; Hiromori, Y.; Nakamura, S.; Kawahara, K.; Fukakusa, S.; Maruno, T.; Noda, M.; Uchiyama, S.; Fukui, K.; Nishikawa, J.-I.; et al. Structural basis for PPAR $\gamma$ transactivation by endocrine-disrupting organotin compounds. Sci. Rep. 2015, 5, 8520. [CrossRef]

46. Ohno, S. Evolution by Gene Duplication; Springer Science \& Business Media: New York, NY, USA, 1970.

47. Panopoulou, G.; Hennig, S.; Groth, D.; Krause, A.; Poustka, A.J.; Herwig, R.; Vingron, M.; Lehrach, H. New Evidence for Genome-Wide Duplications at the Origin of Vertebrates Using an Amphioxus Gene Set and Completed Animal Genomes. Genome Res. 2003, 13, 1056-1066. [CrossRef] 
48. Marlétaz, F.; Firbas, P.N.; Maeso, I.; Tena, J.J.; Bogdanovic, O.; Perry, M.; Wyatt, C.D.R.; de la Calle-Mustienes, E.; Bertrand, S.; Burguera, D.; et al. Amphioxus functional genomics and the origins of vertebrate gene regulation. Nature 2018, 564, 64-70. [CrossRef]

49. Ravi, V.; Venkatesh, B. The Divergent Genomes of Teleosts. Annu. Rev. Anim. Biosci. 2018, 6, 47-68. [CrossRef]

50. Dehal, P.; Boore, J.L. Two Rounds of Whole Genome Duplication in the Ancestral Vertebrate. PLoS Biol. 2005, 3, e314. [CrossRef] [PubMed]

51. Putnam, N.H.; Butts, T.; Ferrier, D.E.K.; Furlong, R.F.; Hellsten, U.; Kawashima, T.; Robinson-Rechavi, M.; Shoguchi, E.; Terry, A.; Yu, J.-K.; et al. The amphioxus genome and the evolution of the chordate karyotype. Nature 2008, 453, 1064-1071. [CrossRef]

52. Nakatani, Y.; Shingate, P.; Ravi, V.; Pillai, N.E.; Prasad, A.; McLysaght, A.; Venkatesh, B. Reconstruction of proto-vertebrate, proto-cyclostome and proto-gnathostome genomes provides new insights into early vertebrate evolution. Nat. Commun. 2021, 12, 1-14. [CrossRef] [PubMed]

53. Jaillon, O.; Aury, J.-M.; Brunet, F.; Petit, J.-L.; Stange-Thomann, N.; Mauceli, E.; Bouneau, L.; Fischer, C.; Ozouf-Costaz, C.; Bernot, A.; et al. Genome duplication in the teleost fish Tetraodon nigroviridis reveals the early vertebrate proto-karyotype. Nature 2004, 431, 946-957. [CrossRef]

54. Berthelot, C.; Brunet, F.; Chalopin, D.; Juanchich, A.; Bernard, M.; Noel, B.; Bento, P.; DA Silva, C.; Labadie, K.; Alberti, A.; et al The rainbow trout genome provides novel insights into evolution after whole-genome duplication in vertebrates. Nat. Commun. 2014, 5, 3657. [CrossRef] [PubMed]

55. Rondeau, E.B.; Minkley, D.R.; Leong, J.S.; Messmer, A.M.; Jantzen, J.R.; Von Schalburg, K.R.; Lemon, C.; Bird, N.H.; Koop, B.F. The Genome and Linkage Map of the Northern Pike (Esox lucius): Conserved Synteny Revealed between the Salmonid Sister Group and the Neoteleostei. PLoS ONE 2014, 9, e102089. [CrossRef] [PubMed]

56. Lien, S.; Koop, B.F.; Sandve, S.R.; Miller, J.R.; Kent, M.P.; Nome, T.; Hvidsten, T.R.; Leong, J.S.; Minkley, D.R.; Zimin, A.; et al. The Atlantic salmon genome provides insights into rediploidization. Nature 2016, 533, 200-205. [CrossRef]

57. Leaver, M.J.; Boukouvala, E.; Antonopoulou, E.; Diez, A.; Favre-Krey, L.; Ezaz, M.T.; Bautista, J.M.; Tocher, D.R.; Krey, G. Three Peroxisome Proliferator-Activated Receptor Isotypes from Each of Two Species of Marine Fish. Endocrinology 2005, 146, 3150-3162. [CrossRef]

58. Braasch, I.; Postlethwait, J.H. Polyploidy in fish and the teleost genome duplication. In Polyploidy and Genome Evolution; Soltis, P.S., Soltis, D.E., Eds.; Springer: Berlin/Heidelberg, Germany, 2012; pp. 341-383.

59. Urbatzka, R.; Galante-Oliveira, S.; Rocha, E.; Castro, L.F.C.; Cunha, I. Tissue expression of PPAR-alpha isoforms in Scophthalmus maximus and transcriptional response of target genes in the heart after exposure to WY-14643. Fish Physiol. Biochem. 2013, 39, 1043-1055. [CrossRef]

60. Urbatzka, R.; Galante-Oliveira, S.; Rocha, E.; Lobo-Da-Cunha, A.; Castro, L.F.C.; Cunha, I. Effects of the PPAR $\alpha$ agonist WY-14,643 on plasma lipids, enzymatic activities and mRNA expression of lipid metabolism genes in a marine flatfish, Scophthalmus maximus. Aquat. Toxicol. 2015, 164, 155-162. [CrossRef]

61. Cunha, I.; Galante-Oliveira, S.; Rocha, E.; Urbatzka, R.; Castro, L.F.C. Expression of intercellular lipid transport and cholesterol metabolism genes in eggs and early larvae stages of turbot, Scophthalmus maximus, a marine aquaculture species. Mar. Biol. 2015, 162, 1673-1683. [CrossRef]

62. Hughes, L.C.; Ortí, G.; Huang, Y.; Sun, Y.; Baldwin, C.C.; Thompson, A.W.; Arcila, D.; Betancur, R.-R.; Li, C.; Becker, L.; et al. Comprehensive phylogeny of ray-finned fishes (Actinopterygii) based on transcriptomic and genomic data. Proc. Natl. Acad. Sci. USA 2018, 115, 6249-6254. [CrossRef]

63. Keller, H.; Dreyer, C.; Medin, J.; Mahfoudi, A.; Ozato, K.; Wahli, W. Fatty acids and retinoids control lipid metabolism through activation of peroxisome proliferator-activated receptor-retinoid X receptor heterodimers. Proc. Natl. Acad. Sci. USA 1993, 90, 2160-2164. [CrossRef]

64. Kliewer, S.A.; Sundseth, S.S.; Jones, S.A.; Brown, P.J.; Wisely, G.B.; Koble, C.S.; Devchand, P.; Wahli, W.; Willson, T.M.; Lenhard, J.M.; et al. Fatty acids and eicosanoids regulate gene expression through direct interactions with peroxisome proliferatoractivated receptors $\alpha$ and $\gamma$. Proc. Natl. Acad. Sci. USA 1997, 94, 4318-4323. [CrossRef]

65. O'Sullivan, S.E. An update on PPAR activation by cannabinoids. Br. J. Pharmacol. 2016, 173, 1899-1910. [CrossRef]

66. Hummasti, S.; Tontonoz, P. The Peroxisome Proliferator-Activated Receptor N-Terminal Domain Controls Isotype-Selective Gene Expression and Adipogenesis. Mol. Endocrinol. 2006, 20, 1261-1275. [CrossRef] [PubMed]

67. International Maritime Organization (IMO). Anti-Fouling Systems. 2002, pp. 1-31. Available online: https://www.imo.org/en/ OurWork/Environment/Pages/Anti-fouling.aspx (accessed on 15 February 2021).

68. Appel, K.E. Organotin Compounds: Toxicokinetic Aspects. Drug Metab. Rev. 2004, 36, 763-786. [CrossRef]

69. Okoro, H.K.; Fatoki, O.S.; Adekola, F.A.; Ximba, B.J.; Snyman, R.G.; Opeolu, B. Human Exposure, Biomarkers, and Fate of Organotins in the Environment. Rev. Environ. Contam. Toxicol. Vol. 2011, 213, 27-54. [CrossRef]

70. Matthiessen, P.; Gibbs, P.E. Critical appraisal of the evidence for tributyltin-mediated endocrine disruption in mollusks. Environ. Toxicol. Chem. 1998, 17, 37-43. [CrossRef]

71. Lima, D.; Reis-Henriques, M.A.; Silva, R.; Santos, A.I.; Castro, L.F.C.; Santos, M.M. Tributyltin-induced imposex in marine gastropods involves tissue-specific modulation of the retinoid X receptor. Aquat. Toxicol. 2011, 101, 221-227. [CrossRef]

72. McAllister, B.G.; Kime, D.E. Early life exposure to environmental levels of the aromatase inhibitor tributyltin causes masculinisation and irreversible sperm damage in zebrafish (Danio rerio). Aquat. Toxicol. 2003, 65, 309-316. [CrossRef] 
73. Shimasaki, Y.; Kitano, T.; Oshima, Y.; Inoue, S.; Imada, N.; Honjo, T. Tributyltin causes masculinization in fish. Environ. Toxicol. Chem. 2003, 22, 141-144. [CrossRef]

74. Grn, F.; Watanabe, H.; Zamanian, Z.; Maeda, L.; Arima, K.; Cubacha, R.; Gardiner, D.M.; Kanno, J.; Iguchi, T.; Blumberg, B. Endocrine-Disrupting Organotin Compounds Are Potent Inducers of Adipogenesis in Vertebrates. Mol. Endocrinol. 2006, 20, 2141-2155. [CrossRef]

75. Grün, F.; Blumberg, B. Minireview: The Case for Obesogens. Mol. Endocrinol. 2009, 23, 1127-1134. [CrossRef]

76. le Maire, A.; Grimaldi, M.; Roecklin, D.; Dagnino, S.; Vivat-Hannah, V.; Balaguer, P.; Bourguet, W. Activation of RXR-PPAR heterodimers by organotin environmental endocrine disruptors. EMBO Rep. 2009, 10, 367-373. [CrossRef] [PubMed]

77. Caubère, P.; Coutrot, P. Reduction of sulfur-carbon bonds and of other heteroatoms bonded to tetrahedral carbon. In Comprehensive Organic Synthesis; Trost, B.M., Fleming, I., Eds.; Pergamon Press: Oxford, UK, 1991; Volume 8, pp. 835-870.

78. Fonseca, E.; Ruivo, R.; Borges, D.; Franco, J.N.; Santos, M.M.; Castro, L.F.C. Of Retinoids and Organotins: The Evolution of the Retinoid X Receptor in Metazoa. Biomolecules 2020, 10, 594. [CrossRef] [PubMed]

79. Zhu, Y.; Qi, C.; Korenberg, J.R.; Chen, X.N.; Noya, D.; Rao, M.S.; Reddy, J.K. Structural organization of mouse peroxisome proliferator-activated receptor gamma (mPPAR gamma) gene: Alternative promoter use and different splicing yield two mPPAR gamma isoforms. Proc. Natl. Acad. Sci. USA 1995, 92, 7921-7925. [CrossRef] [PubMed]

80. Fajas, L.; Auboeuf, D.; Raspé, E.; Schoonjans, K.; Lefebvre, A.-M.; Saladin, R.; Najib, J.; Laville, M.; Fruchart, J.-C.; Deeb, S.; et al. The Organization, Promoter Analysis, and Expression of the Human PPAR $\gamma$ Gene. J. Biol. Chem. 1997, 272, 18779-18789. [CrossRef] [PubMed] 